\title{
NILAI DESAIN ACUAN SAMBUNGAN KAYU GESER GANDA DENGAN PAKU BERPELAT SISI BAJA AKIBAT BEBAN UNI-AKSIAL TEKAN MENURUT BERBAGAI ANALISIS PENDEKATAN
}

\author{
Reference Design Value of Double Shear Timber Connections with Steel Side Plates Nail Under Uni-Axial \\ Compression Loading According to Various Approximation Analysis
}

Sucahyo Sadiyo, Naresworo Nugroho, Surjono Surjokusumo dan Imam Wahyudi

\begin{abstract}
The purposes of this research are to know the influence of woods specific gravity and nail diameter to reference design value in double shear timber connections with steel side plates nail on four species of Indonesian commercial wood according to various approximation analysis. Analysis is done to four values and it is compared with other research that has been done. This research result from testing which have done by Ziannita (2009) referred as approach of A; result of research of Sadiyo and Sriyanto (2009) and Mansur (2009) referred as approach of B; values referring at literature referred as approach of $C$ and compressive-joint total load divided by nail amount and factor of safety referred as approach of $D$ (Sadiyo and Sriyanto, 2009 and Mansur, 2009). Joint done by using four species of Indonesian commercial wood which is meranti merah (Shorea leprosula), mabang (Shorea pachyphylla), kempas (Koompassia malaccensis) and bangkirai (Shorea laevifolia). Nails that applied in this research are nail with diameter of $4.1 \mathrm{~mm}$ length of $10 \mathrm{~cm}$, nail with diameter of $5.2 \mathrm{~mm}$ length of $12.5 \mathrm{~cm}$ and nail with diameter of $5.5 \mathrm{~mm}$ length of $15 \mathrm{~cm}$. The calculation of this research is done according to National Design Specification for Wood Construction-2005. Analysis results indicate that wood specific gravity influence the strength of connection, excelsior wood specific gravity will produce high strength of connection also. This can be influenced by mechanical properties from wood such as maximum crushing strength. Bangkirai have higher specific gravity than three others wood but result approach of $D$ shows that the connections assess reference design value which is lower compared with two other woods (kempas and mabang wood). Then, the bigger on nail diameter brings bigger strength of connection also, but this thing depends on the conditions from nail and quality of nail materials.
\end{abstract}

Key words: compression loading, double shear connections, nail, reference design value, steel side plates.

\section{PENDAHULUAN}

Bangunan struktural sebagai bagian dari konstruksi teknik dirancang dengan memperhitung kan persyaratan keamanan yang tinggi demi keselamatan dan kenyamanan penghuninya. Pada semua konstruksi teknik bagian-bagian pelengkap suatu bangunan harus diberi ukuranukuran fisik yang akurat agar dapat menahan gaya-gaya yang sesungguhnya atau yang mungkin akan diberikan kepadanya.

Pada prinsipnya suatu bangunan struktural menuntut tiga aspek penting, yaitu kekakuan (stiffness), kekuatan (strength) dan kestabilan (stability) struktur. Kekuatan, kekakuan dan kestabilan suatu bangunan struktural kayu dipengaruhi oleh berbagai faktor di antaranya bentuk rancang bangun, jenis kayu yang digunakan dan macam/jenis sambungan. Menurut Tular dan Idris (1981) sambungan merupakan titik kritis atau terlemah dari suatu konstruksi. Titik kritis sebuah sambungan konstruksi harus mampu menerima dan menahan beban yang terjadi. Kekuatan sambungan kayu sangat dipengaruhi oleh komponen pembentuk sambungan, yaitu balok kayu yang akan disambung, alat sambung (paku atau pelat sambung) dan bentuk sambungan yang akan dibuat. Balok kayu yang digunakan dalam pembuatan sambungan akan mempengaruhi kekuatan karena adanya perbedaan sifat fisis maupun sifat mekanis dari setiap jenis kayu. Begitu pula dengan alat 
sambung yang digunakan, jumlah maupun ukuran alat sambung akan turut mempengaruhi kekuatan sambungan. Dengan demikian sambungansambungan kayu sekarang ini menurut Faherty dan Williamson (1989) dapat didisain dengan ketelitian yang sama seperti bagian-bagian lain dari struktur.

Alat sambung yang dapat digunakan dalam penyambungan adalah berupa pelat sambung dan paku. Pelat sambung akan membentuk sambungan dengan mudah dan diharapkan dapat meningkatkan kekuatan sambungan. Paku merupakan salah satu alat sambung mekanik (mechanical joint) yang dapat digunakan dalam membuat sambungan kayu. Keuntungan dalam menggunakan paku sebagai alat sambung adalah relatif murah dan mudah dikerjakan.

Menurut Surjokusumo dkk. (1980) variabel yang digunakan untuk melihat dan menduga besarnya beban yang bekerja pada suatu sambungan adalah diameter paku, jumlah paku, dan berat jenis kayu. Berdasarkan uraian di atas, maka dilakukan penelitian untuk mengetahui pengaruh variabel - variabel di atas terhadap kekuatan lentur paku dan kekuatan paku yang dibenamkan ke dalam empat jenis kayu yang memiliki berat jenis yang berbeda dengan ukuran paku yang berbeda pula.

Tujuan penelitian ini adalah untuk mengetahui pengaruh diameter paku dan berat jenis kayu terhadap kekuatan sambungan kayu double shear dengan paku berpelat sisi baja empat jenis kayu perdagangan Indonesia. Penelitian ini juga bertujuan untuk mengetahui nilai desain acuan sambungan kayu geser ganda (double shear) dengan paku berpelat sisi baja empat jenis kayu pada beberapa diameter paku menurut berbagai analisis pendekatan.

\section{BAHAN DAN METODE}

\section{Waktu dan Tempat}

Penelitian kuat lentur paku menurut diameter paku serta kuat tumpu paku ke dalam balok 4 jenis kayu dilakukan selama kurang lebih tiga bulan yaitu dari bulan Mei hingga Juli 2009. Pembagian waktu didasarkan pada dua kelompok kegiatan yaitu penyiapan bahan kayu dan pembuatan contoh uji untuk pembenaman paku ke dalam balok dikerjakan kurang lebih dua bulan sedangkan pengujian dilakukan selama kurang lebih satu bulan.

Penyiapan bahan kayu dan contoh uji dilakukan di workshop penggergajian kayu Laboratorium Peningkatan Mutu Hasil Hutan. Sedangkan pengujian contoh uji dilakukan di Laboratorium Rekayasa dan Desain Bangunan Kayu, Departemen Hasil Hutan, Fakultas Kehutanan, Institut Pertanian Bogor.

\section{Metode Penelitian}

Pengujian sifat fisis kayu yang diteliti meliputi kerapatan, berat jenis, kadar air sedangkan untuk pengujian sifat mekanis meliputi kuat lentur paku dan kuat tumpu paku. Pengujian ini menggunakan Universal Testing Machine merk Instron series IX version 8.27.00.

\section{Kadar Air}

Contoh uji ditimbang beratnya untuk mengetahui berat awal (kering udara) sebelum dimasukan ke dalam oven. Selanjutnya contoh uji dimasukan ke dalam oven dengan suhu $(103 \pm 2)^{\circ} \mathrm{C}$ selama 24 jam kemudian contoh uji dikeluarkan dan ditimbang beratnya untuk memperoleh berat kering oven (bila beratnya telah konstan). Perhitungan kadar air dilakukan dengan menggunakan rumus sebagai berikut:

$$
K A_{K U}=\frac{B_{K U}-B_{K T}}{B_{K T}} \times 100 \%
$$

\section{Kerapatan dan berat jenis kayu}

Pengujian kerapatan kayu dilakukan dengan cara menimbang contoh uji untuk mengetahui berat awal (kondisi kering udara), kemudian volume contoh uji dihitung dengan cara mengalikan panjang, lebar dan tebalnya. Dimensi contoh uji tersebut diukur dengan menggunakan calipper. Nilai kerapatan contoh uji dihitung berdasarkan rumus sebagai berikut:

$$
\text { Kerapatan }\left(\frac{\mathrm{g}}{\mathrm{cm}^{3}}\right)=\frac{\text { berat contoh uf }(g)}{\text { volume contoh ufi }\left(\mathrm{cm}^{3}\right)}
$$

Perhitungan berat jenis dalam penelitian ini didasarkan atas asumsi dan penyederhanaan pendekatan di mana dalam sistim metrik air sebanyak $1 \mathrm{~cm}^{3}$ pada suhu kamar beratnya dianggap sebesar $1 \mathrm{~g}$. Jadi berat jenis dapat 
dihitung secara langsung dengan membagi berat kering tanur dalam $\mathrm{g}$ dengan volume dalam $\mathrm{cm}^{3}$. Dengan angka maka kerapatan dan berat jenis adalah sama. Namun berat jenis tidak mempunyai satuan karena berat jenis adalah nilai relatif. Nilai berat jenis dapat diperoleh dengan rumus:

$$
\text { Berat Jenis }=\frac{\left(\frac{\text { massa kering tanur }}{\text { volume }}\right)}{\text { kerapatan air }}
$$

\section{Pengujian kuat tumpu paku}

Pengujian kuat tumpu paku (nail bearing strength) adalah pengujian sifat mekanis berupa pembenaman paku ke dalam balok kayu. Pengujian ini dilakukan dengan menggunakan Universal Testing Machine merk Instron series IX version 8.27.00. Pengujian sifat mekanis kuat tumpu paku tersebut dilakukan dengan cara memberikan beban merata perlahan-lahan sepanjang sumbu paku sampai paku terbenam dalam contoh uji. Beban tersebut merupakan beban maksimum yang dapat diterima oleh contoh uji. Untuk mendapatkan nilai kuat tumpu paku $\left(\boldsymbol{F}_{\mathrm{em}}\right)$ dapat digunakan rumus sebagai berikut:

$$
\boldsymbol{F}_{\mathrm{em}}(\text { psi })=\frac{\boldsymbol{P}_{\max }}{\boldsymbol{b} \boldsymbol{h}}
$$

Untuk kekuatan paku yang terdapat pada pelat baja (side member) digunakan nilai sebesar :

$$
F_{e s}(p s i)=61850
$$

Nilai ini berasal dari National Design Specification (NDS) pendukung 2005.

\section{Pengujian kuat lentur paku}

Pengujian kuat lentur paku (bending yield strength) adalah pengujian sifat mekanis. Pengujian ini dilakukan dengan menggunakan Universal Testing Machine merk Instron series IX version 8.27.00. Pengujian sifat mekanis kuat lentur paku tersebut dilakukan dengan memberikan beban secara perlahan-lahan pada arah tegak lurus sumbu paku tunggal sampai contoh uji mengalami kerusakan. Beban tersebut merupakan beban maksimum yang dapat diterima oleh contoh uji. Nilai kuat lentur paku dapat diperoleh dengan menggunakan rumus berikut:

$$
F_{y b}(p s i)=\frac{P_{\max } L}{\pi r^{3}}
$$

\section{Analisis Data}

Pengolahan data menggunakan program Microsoft Office Excel. Pengujian ini dimaksudkan untuk melihat perbedaan kekuatan sambungan paku antara pengaruh tiap faktor maupun kombinasi antara perlakuan penggunaan diameter dan panjang paku dengan berat jenis masingmasing kayu. Hasil penelitian ini berbasis kuat tumpu paku dan uji lentur paku (Ziannita, 2009) selanjutnya dinamakan sebagai pendekatan $A$; untuk penelitian Sadiyo dan Sriyanto (2009) serta Mansur (2009) berbasis berat jenis sebagai pendekatan B; untuk acuan literatur/studi pustaka berbasis jenis kayu atau berat jenis sebagai pendekatan $\mathrm{C}$ serta untuk penelitian Sadiyo dan Sriyanto (2009) dan Mansur (2009) berbasis beban per paku dari sambungan paku majemuk selanjutnya dinamakan sebagai pendekatan $D$. Masing-masing pendekatan tersebut dianalisis secara deskriptif.

\section{Model Matematis}

Data diolah dengan menggunakan rumus "Yield Limit Equation" untuk sambungan double shear menurut NDS (National Design Spesification for Wood Contruction) pendukung 2005.

Table 1. Yield limit equation for double shear connections

\begin{tabular}{cc}
\hline Yield Mode & double shear connections \\
\hline Im & $Z=\frac{D \text { lm Fem }}{R d}$ \\
Is & $Z=\frac{2 D \text { ls Fes }}{R d}$ \\
IIIs & $Z=\frac{2 k_{3} D \text { ls Fem }}{(2+R e) R d}$ \\
IV & $Z=\frac{2 D^{2}}{R d} \sqrt{\frac{2 F e m F y b}{3(1+R e)}}$
\end{tabular}

Remarks:

$Z=$ reference design value, $\mathrm{lb}$

$D=$ nail diameter, in.

$F_{y b}=$ nail bending yield strength, psi

$I_{m}=$ main member nail bearing length, in. 
Is = side member nail bearing length, in.

$F_{\text {em }}=$ main member nail bearing strength, psi

$F_{\text {es }}=$ side member nail bearing strength, psi

$\boldsymbol{R}_{\boldsymbol{d}}=$ reduction term (see Table 2 )

$k_{3}=-1+\sqrt{\frac{2(1+R \theta)}{R e}+\frac{2 F_{y b}(2+R \theta) D^{2}}{3 F_{e m} l^{2} s}}$

$\boldsymbol{R}_{e}=\frac{F_{e m}}{F_{e s}}$

Table 2. Reduction Term, $R_{d}$

\begin{tabular}{|c|c|c|}
\hline Fastener Size & Yield Mode & $R_{d}$ \\
\hline $0.25^{\prime \prime} \leq \mathrm{D} \leq 1 "$ & $\begin{array}{c}\mathrm{Im}, \mathrm{Is} \\
\| \\
\|\mathrm{IIm}, I\| \mathrm{s}, \mathrm{IV} \\
\mathrm{Im}, \mathrm{Is}, \| \mathrm{I}, \mathrm{IIm}, \mathrm{IIIs}, \mathrm{IV}\end{array}$ & $\begin{array}{l}4 \mathrm{~K}_{\ominus} \\
\mathrm{K}_{\ominus} \\
\mathrm{K}_{\ominus} \\
\mathrm{K}^{1}\end{array}$ \\
\hline \multicolumn{3}{|c|}{$\begin{array}{l}\text { Sources: National Design Spesification for Wood } \\
\text { Construction, } 2005\end{array}$} \\
\hline \multirow{2}{*}{\multicolumn{3}{|c|}{$\begin{array}{l}\text { Notes: } \\
\mathrm{K}_{\ominus}=1+0.25(\Theta / 90)\end{array}$}} \\
\hline & & \\
\hline \multicolumn{3}{|c|}{$\begin{aligned} \theta= & \text { maximum angle of load to grain }\left(0^{\circ} \leq \theta \leq\right. \\
& \left.90^{\circ}\right) \text { for any member in a connection. } \\
D= & \text { diameter, in. }\end{aligned}$} \\
\hline $\begin{array}{l}\mathrm{D}=\text { diameter } \\
\mathrm{K}_{\mathrm{D}}=2.2 \\
\mathrm{~K}_{\mathrm{D}}=10 \mathrm{D}+0.5\end{array}$ & $\begin{array}{l}\text { for } D \leq 0.17^{\prime \prime} \\
\text { for } 0.17^{\prime \prime} \leq D \leq 0.2\end{array}$ & \\
\hline
\end{tabular}

\section{HASIL DAN PEMBAHASAN}

\section{Sifat Fisik Kayu}

Kadar air kayu adalah berat air yang dinyatakan sebagai persen berat kayu bebas air atau kandungan air pada kayu dalam keadaan kering tanur (Haygreen dan Bowyer 1993). Nilai kadar air kayu dapat dilihat pada gambar berikut.

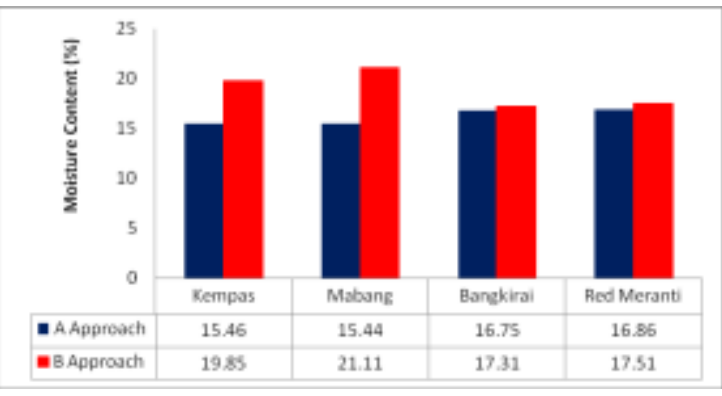

Figure 1. Moisture content of four wood species

Kadar air kayu yang dihasilkan dari data pendekatan A pada empat jenis kayu memiliki nilai yang hampir sama dimana nilai kadar airnya berkisar antara $15,44 \%$ sampai $16,86 \%$. sedangkan pada data pendekatan B nilai kadar airnya berkisar antara $17,31 \%$ sampai $21,11 \%$.
Nilai kadar air paling tinggi terdapat pada data pendekatan B pada kayu mabang sebesar 21,1\% dan terendah juga pada kayu yang sama sebesar $15,44 \%$ (pendekatan A). Perbedaan kadar air empat jenis kayu ini (pendekatan B) diduga lebih disebabkan berbagai faktor tetapi terutama oleh waktu penyimpanan atau pengeringan alami yang terlalu singkat (2 bulan) sehingga kayu mabang misalnya belum mencapai kadar air kesetimbangan (KAK) dengan suhu dan kelembaban udara relatif di sekitarnya.

Nilai kerapatan dari empat jenis kayu tersebut dapat dilihat dalam gambar berikut ini:

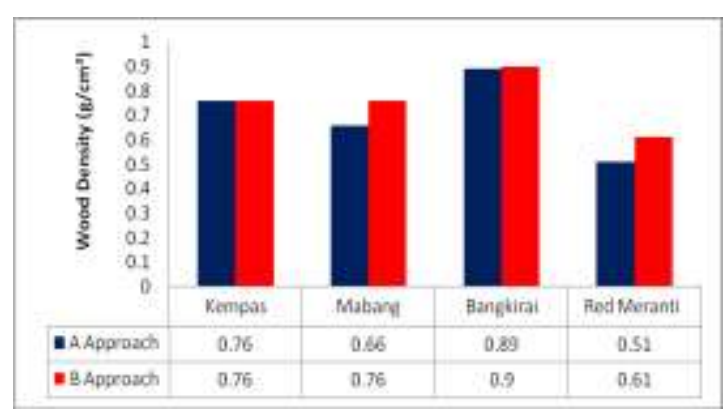

Figure 2. Density of four wood species

Secara keseluruhan nilai kerapatan empat jenis kayu sangat bervariasi. Kerapatan kayu tertinggi pada data pendekatan A terdapat pada kayu bangkirai sebesar $0,89 \mathrm{~g} / \mathrm{cm}^{3}$. Hal ini juga terjadi pada data pendekatan $B$ di mana kerapatan tertinggi terdapat pada kayu bangkirai sebesar $0,90 \mathrm{~g} / \mathrm{cm}^{3}$. Nilai kerapatan terendah dari kedua jenis data diperoleh dari jenis kayu yang sama yaitu meranti merah di mana nilainya masing-masing sebesar $0,51 \mathrm{~g} / \mathrm{cm}^{3}$ (pendekatan A) dan $0,61 \mathrm{~g} / \mathrm{cm}^{3}$ (pendekatan B). Nilai kerapatan kayu dapat menggambarkan kekuatan kayu di mana nilai tersebut berbanding lurus, semakin besar kerapatan kayu maka semakin kuat pula kayu tersebut

Berat jenis adalah perbandingan antara kerapatan kayu (atas dasar berat kering tanur dan volume pada kandungan yang telah ditentukan) dengan kerapatan air pada keadaan standar (pada suhu $4^{\circ} \mathrm{C}$ air memiliki kerapatan $1 \mathrm{~g} / \mathrm{cm}^{3}$ ). Nilai berat jenis empat jenis kayu dapat dilihat pada Gambar 3.

Berat jenis kayu merupakan salah satu sifat fisis kayu yang sangat penting untuk mengetahui seberapa jauh kekuatan dan ketahanan kayu dalam menerima gaya atau beban dari luar. 


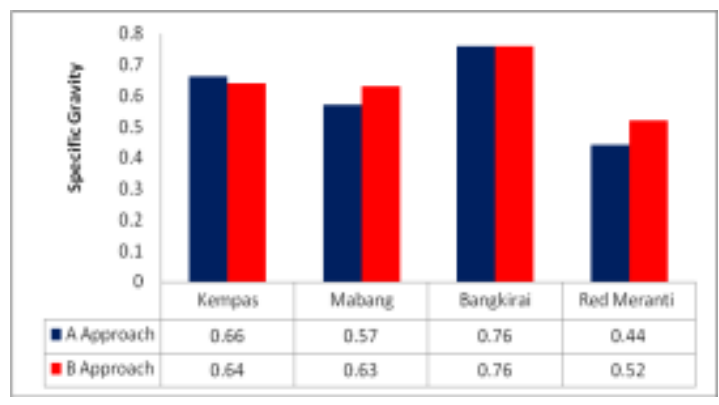

Figure 3. Specific gravity of four wood species

Tabarsa dan Chui (2001) menunjukkan bahwa perilaku kayu dalam tekan arah transversal sangat bergantung pada ciri-ciri anatomi kayu tersebut. Berbeda dengan Beery et al. (1983) perilaku elastis lebih tergantung pada kerapatan dari pada sifat atau karakteristik anatomi kayu. Kennedy (1968) dalam Muller, et al. (2003) memperkuat kecenderungan pengaruh kerapatan dan juga menemukan hubungan antara perilaku mekanis dengan proporsi kayu akhir serta perbedaanperbedaan kayu awal dengan kayu akhir.

\section{Sifat Mekanis Sambungan Paku}

\section{Kuat Lentur Paku}

Pengujian lentur paku dilakukan dengan tujuan untuk mengetahui kuat lentur maksimum (nail bending yield strength) dari sebuah paku dalam menerima beban lentur. Paku ditekan dengan beban di tengah bentang pada arah tegak lurus sumbu paku dan menghasilkan nilai $\boldsymbol{F}_{y b}$ (kuat lentur paku) yang disajikan pada Tabel 3.

Table 3. Nail bending yield strength $\left(F_{y b}\right)$ according to three size of nail diameter

\begin{tabular}{ccc}
\hline $\begin{array}{c}\text { Nail Diameter } \\
(\mathrm{mm})\end{array}$ & $\begin{array}{c}F_{\mathrm{yb}} \\
\left(\mathrm{kgf} / \mathrm{cm}^{2}\right)\end{array}$ & $\begin{array}{c}F_{\mathrm{yb}} \\
(\mathrm{psi})\end{array}$ \\
\hline 4.1 & 14845 & 211149 \\
5.2 & 15798 & 224700 \\
5.5 & 11280 & 160441 \\
\hline
\end{tabular}

\section{Kuat Tumpu Paku}

Kuat tumpu paku merupakan suatu sifat mekanik bahan yang ditentukan berdasarkan hasil uji yang menggambarkan kuat batas dari kayu disekeliling lubang yang dibebani tekan oleh paku. Nilai tersebut diperoleh dengan cara membagi beban maksimum terhadap luasan daerah kayu yang terbenam oleh paku, disimbolkan dengan notasi Fem (kekuatan paku yang masuk ke dalam main member, psi.).

Table 4. Nail bearing strength in main member $\left(F_{\text {em }}\right)$ for four wood species according to nail diameter

\begin{tabular}{ccc}
\hline Wood species & Nail Diameter $(\mathrm{mm})$ & $\begin{array}{c}F_{\text {em }} \\
(\mathrm{psi})\end{array}$ \\
\hline \multirow{3}{*}{ Red Meranti } & 4.1 & 3302 \\
& 5.2 & 3410 \\
& 5.5 & 3360 \\
\hline \multirow{3}{*}{ Mabang } & 4.1 & 4375 \\
& 5.2 & 4896 \\
Kempas & 5.5 & 4955 \\
\hline \multirow{3}{*}{ Bangkirai } & 4.1 & 4930 \\
& 5.2 & 7181 \\
& 5.5 & 6898 \\
\hline & 4.1 & 6428 \\
& 5.2 & 7076 \\
& 5.5 & 7344 \\
\hline
\end{tabular}

\section{Persamaan Batas Leleh}

Persamaan batas leleh (yield limit equation) pertama kali diperkenalkan oleh Johansen (1949) berdasarkan prinsip mekanika teknik untuk memprediksi kuat lentur paku dan tahanan kayu saat hancur (kuat tumpu paku). Persamaan tersebut selanjutnya dikenal dengan nama nilai disain acuan atau reference design value ( $Z$ ).

Nilai $Z$ yang dibandingkan adalah persamaan batas (mode) IV, karena nilai tersebut hasilnya minimum dari ketiga nilai $Z$ mode lainnya dan ini berarti mode IV merupakan bentuk kerusakan yang dianggap paling kritis dan terlemah. Mode IV inilah yang dibandingkan dengan sesaran 0,38 $\mathrm{mm}, 0,8 \mathrm{~mm}, 1,5 \mathrm{~mm}$ dan $5 \mathrm{~mm}$ pada data pendekatan $D$. Nilai yield limit equation atau nilai disain tegangan ijin (format $A S D$ ) yang terkecil digunakan sebagai dasar dalam menentukan kekuatan sebuah paku pada aplikasi struktural. Displacement atau sesaran tersebut ditetapkan berdasarkan standar yang berlaku di beberapa negara yaitu Amerika menetapkan sesaran 0,38 $\mathrm{mm}$ berdasarkan Forest products Laboratory (1999), Australia 0,8 mm bedasarkan Standard Association of Australia (SAA), Indonesia $1,5 \mathrm{~mm}$ berdasarkan PKKI-61 dan sesaran $5 \mathrm{~mm}$ merupakan batas yang diduga sambungan paku 
Table 5. Reference design value $\mathrm{Z}(\mathrm{kg})$ of double shear connections of red meranti with nail fastener

\begin{tabular}{|c|c|c|c|c|c|c|}
\hline \multirow{2}{*}{$\begin{array}{l}\text { Yield } \\
\text { Mode }\end{array}$} & \multirow{2}{*}{$\begin{array}{l}\text { Nail diameter } \\
(\mathrm{mm})\end{array}$} & \multicolumn{4}{|c|}{ Approach } & \multirow{2}{*}{ Displacement (mm) } \\
\hline & & $A$ & $B$ & $C$ & $D$ & \\
\hline \multirow{12}{*}{ IV } & \multirow{4}{*}{4.1} & \multirow{4}{*}{226} & \multirow{4}{*}{158} & \multirow{4}{*}{185} & 43 & 0.38 \\
\hline & & & & & 88 & 0.8 \\
\hline & & & & & 146 & 1.5 \\
\hline & & & & & 163 & 5 \\
\hline & \multirow{4}{*}{5.2} & \multirow{4}{*}{329} & \multirow{4}{*}{191} & \multirow{4}{*}{244} & 89 & 0.38 \\
\hline & & & & & 151 & 0.8 \\
\hline & & & & & 239 & 1.5 \\
\hline & & & & & 166 & 5 \\
\hline & \multirow{4}{*}{5.5} & \multirow{4}{*}{295} & \multirow{4}{*}{208} & \multirow{4}{*}{257} & 80 & 0.38 \\
\hline & & & & & 142 & 0.8 \\
\hline & & & & & 278 & 1.5 \\
\hline & & & & & 209 & 5 \\
\hline
\end{tabular}

Table 6. Reference design value $Z$ ( $\mathrm{kg}$ ) of double shear connections of mabang wood with nail fastener

\begin{tabular}{|c|c|c|c|c|c|c|}
\hline \multirow{2}{*}{$\begin{array}{l}\text { Yield } \\
\text { Mode }\end{array}$} & \multirow{2}{*}{$\begin{array}{c}\text { Nail diameter } \\
(\mathrm{mm})\end{array}$} & \multicolumn{4}{|c|}{ Approach } & \multirow{2}{*}{$\begin{array}{r}\text { Displacement } \\
(\mathrm{mm})\end{array}$} \\
\hline & & A & B & C & D & \\
\hline \multirow{12}{*}{ IV } & \multirow{4}{*}{4.1} & \multirow{4}{*}{258} & \multirow{4}{*}{218} & \multirow{4}{*}{256} & 189 & 0.38 \\
\hline & & & & & 280 & 0.8 \\
\hline & & & & & 341 & 1.5 \\
\hline & & & & & 218 & 5 \\
\hline & \multirow{4}{*}{5.2} & \multirow{4}{*}{390} & \multirow{4}{*}{276} & \multirow{4}{*}{337} & 184 & 0.38 \\
\hline & & & & & 356 & 0.8 \\
\hline & & & & & 502 & 1.5 \\
\hline & & & & & 276 & 5 \\
\hline & \multirow{4}{*}{5.5} & \multirow{4}{*}{354} & \multirow{4}{*}{291} & \multirow{4}{*}{355} & 84 & 0.38 \\
\hline & & & & & 159 & 0.8 \\
\hline & & & & & 300 & 1.5 \\
\hline & & & & & 272 & 5 \\
\hline
\end{tabular}

Table 7. Reference design value Z $(\mathrm{kg})$ of double shear connections of kempas wood with nail fastener

\begin{tabular}{|c|c|c|c|c|c|c|}
\hline \multirow{2}{*}{$\begin{array}{l}\text { Yield } \\
\text { Mode }\end{array}$} & \multirow{2}{*}{$\begin{array}{c}\text { Nail } \\
\text { diameter }(\mathrm{mm})\end{array}$} & \multicolumn{4}{|c|}{ Approach } & \multirow{2}{*}{ Displacement $(\mathrm{mm})$} \\
\hline & & $A$ & $B$ & $\mathrm{C}$ & $\mathrm{D}$ & \\
\hline \multirow{12}{*}{ IV } & \multirow{4}{*}{4.1} & \multirow{4}{*}{273} & \multirow{4}{*}{221} & \multirow{4}{*}{300} & 178 & 0.38 \\
\hline & & & & & 277 & 0.8 \\
\hline & & & & & 376 & 1.5 \\
\hline & & & & & 225 & 5 \\
\hline & \multirow{4}{*}{5.2} & \multirow{4}{*}{464} & \multirow{4}{*}{276} & \multirow{4}{*}{396} & 229 & 0.38 \\
\hline & & & & & 414 & 0.8 \\
\hline & & & & & 586 & 1.5 \\
\hline & & & & & 327 & 5 \\
\hline & \multirow{4}{*}{5.5} & \multirow{4}{*}{412} & \multirow{4}{*}{291} & \multirow{4}{*}{417} & 126 & 0.38 \\
\hline & & & & & 204 & 0.8 \\
\hline & & & & & 330 & 1.5 \\
\hline & & & & & 327 & 5 \\
\hline
\end{tabular}


Table 8. Reference design value $Z(\mathrm{~kg})$ of double shear connections of bangkirai wood with nail fastener

\begin{tabular}{|c|c|c|c|c|c|c|}
\hline \multirow{2}{*}{$\begin{array}{l}\text { Yield } \\
\text { Mode }\end{array}$} & \multirow{2}{*}{$\begin{array}{l}\text { Nail diameter } \\
(\mathrm{mm})\end{array}$} & \multicolumn{4}{|c|}{ Approach } & \multirow{2}{*}{ Displacement (mm) } \\
\hline & & $A$ & B & C & D & \\
\hline \multirow{12}{*}{ IV } & \multirow{4}{*}{4.1} & \multirow{4}{*}{308} & \multirow{4}{*}{228} & \multirow{4}{*}{291} & 41 & 0.38 \\
\hline & & & & & 103 & 0.8 \\
\hline & & & & & 193 & 1.5 \\
\hline & & & & & 243 & 5 \\
\hline & \multirow{4}{*}{5.2} & \multirow{4}{*}{461} & \multirow{4}{*}{290} & \multirow{4}{*}{384} & 116 & 0.38 \\
\hline & & & & & 221 & 0.8 \\
\hline & & & & & 399 & 1.5 \\
\hline & & & & & 331 & 5 \\
\hline & \multirow{4}{*}{5.5} & \multirow{4}{*}{423} & \multirow{4}{*}{322} & \multirow{4}{*}{404} & 109 & 0.38 \\
\hline & & & & & 225 & 0.8 \\
\hline & & & & & 363 & 1.5 \\
\hline & & & & & 352 & 5 \\
\hline
\end{tabular}

telah mengalami kerusakan atau berada di zona inelastis nonlinier. Berikut merupakan tabel nilai Z sambungan geser ganda 4 jenis kayu yang diteliti.Tabel 5-8 memperlihatkan bahwa standar Amerika (Forest Products Laboratory, 1999) memberikan batas aman untuk sambungan geser ganda pada displacement atau sesaran $0,38 \mathrm{~mm}$ yang ditetapkan sebagai batas proporsinal sambungan tipe dowel karena memiliki nilai disain tegangan ijin/Z (format ASD) untuk paku tersebut paling kecil ( terendah) dibandingkan dengan nilai $Z$ yang dihasilkan oleh standar lainnya. Pada sesaran $0,8 \mathrm{~mm}$ sebagai batas aman sesaran yang ditetapkan oleh standar Australia sebenarnya nilai $Z$ yang diperoleh dari pendekatan $D$ juga relatif aman untuk semua jenis kayu yang diteliti kecuali kayu mabang dengan paku $5,2 \mathrm{~mm}$ nilainya sedikit di atas pendekatan $\mathrm{B}$. Hal ini berarti nilai disain tegangan ijin atau kekuatan aman sambungan geser ganda dengan paku bagi 4 jenis kayu tropis Indonesia yang diteliti berdasarkan sesaran yang ditetapkan Amerika dan Australia sangat rendah. Nilai disain yang diperoleh dari persamaan $Z$ menurut pendekatan $A, B$ dan $C$ (teoritis) sangat tinggi atau terlalu jauh dibandingkan dengan uji eksperimental (empiris). Bila diasumsikan pendekatan model batas leleh hasilnya benar maka penetapan sesaran $0,8 \mathrm{~mm}$ khususnya 0,38 $\mathrm{mm}$ sebagai batas aman kekuatan sambungan sangat membahayakan aplikasi konstruksi kayu karena ternyata nilai empiris/aktualnya sangat rendah (salah pendugaan). Dengan demikian kedua negara ini relatif rendah dalam menetapkan batas sesaran sambungan geser ganda dengan paku bagi kayu tropis Indonesia atau dengan kata lain sambungan sebenarnya tidak mampu memikul beban rencana. Standar Indonesia yang menetapkan nilai disain tegangan ijin sambungan paku pada sesaran $1,5 \mathrm{~mm}$ berdasarkan pendekatan $D$ nilai $Z$ yang diperoleh lebih realistis karena sebagian besar berada sedikit di atas pendekatan model/teoritis lainnya baik 4 jenis kayu maupun untuk hampir semua ukuran diameter paku yang diteliti. Pendekatan teoritis menggunakan model/persamaan batas leleh mendekati nilai disain tegangan ijin hasil uji eksperimental. Hal ini berarti Indonesia cukup berani menetapkan batas aman kekuatan sambungan pada sesaran sebesar $1,5 \mathrm{~mm}$. Berdasarkan sebaran data yang ada terdapat kecenderungan bahwa batas aman yang paling moderat (efisiensi tinggi) diperkirakan pada sesaran sekirar 1 - 1,2 mm dengan asumsi sesaran tersebut masih berada di bawah batas proporsional.

Kayu kempas menghasilkan nilai disain tegangan ijin yang paling besar pada sesaran 0,35 $\mathrm{mm}$ yaitu sebesar $229 \mathrm{~kg}$ dengan menggunakan paku diameter $5,2 \mathrm{~mm}$. Sedangkan pada paku diameter 4,1 $\mathrm{mm}$ kayu mabang mampu memberikan nilai disain tegangan ijin terbesar pada sesaran $0,35 \mathrm{~mm}$ dengan nilai $189 \mathrm{~kg}$. Pada paku diameter $5,5 \mathrm{~mm}$ dengan sesaran $0,35 \mathrm{~mm}$ 
didapatkan nilai disain tegangan ijin atau batas aman paling besar dengan menggunakan kayu jenis mabang yang mampu menerima beban sebesar $129 \mathrm{~kg}$. Kedua kayu ini walaupun memiliki berat jenis kayu lebih rendah dari kayu bangkirai tetapi khususnya kayu kempas nilai disain tegangan ijinnya tidak sejalan dengan pernyataan umum, bahwa makin tinggi berat jenis atau semakin tebal dinding sel kayu maka semakin tinggi pula kekuatan kayu atau kekuatan sambungan kayu. Hal ini disebabkan kayu kempas umumnya memiliki serat terpadu (interlock grain) yang dengan susunan saling silang seratnya dapat mengikat erat paku di dalam kayu atau paku sulit merobek kayu arah sejajar serat. Terdapat juga kecenderungan bahwa berdasarkan pendekatan $A$ dan $D$ paku diameter $5,2 \mathrm{~mm}$ memberikan nilai disain tegangan ijin lebih besar dibandingkan diameter paku 4,1 mm ataupun $5,5 \mathrm{~mm}$. Hal ini memperlihatkan bahwa paku dengan diameter besar tidak selalu memiliki nilai $Z$ lebih tinggi dibandingkan paku yang lebih kecil. Paku dengan diameter besar memiliki kuat lentur yang rendah dibanding paku diameter kecil (Breyer et al., 2007). Hal ini merupakan salah satu factor yang diduga menyebabkan perlemahan sambungan paku. Di samping itu apabila bahan dinding sel kayu bersifat brittle (regas atau rapuh) atau memiliki kuat belah atau kuat sejajar serat yang rendah maka paku diameter besar cenderung menyebabkan keretakan saat paku tersebut dibenamkan atau dipalu ke dalam kayu.

Perbedaan nilai kekuatan suatu sambungan tersebut dipengaruhi oleh banyak faktor, di antaranya faktor jenis dan kualitas paku yang digunakan serta kayu yang mempunyai sifat ortotropis sehingga nilainya dapat bervariasi. Dari segi bahan kayunya Courney (2000) mengatakan bahwa perilaku tekan bahan padat seluler seperti kayu dipengaruhi oleh tebal dinding sel, bentuk sel, diameter rongga sel, distribusi kerapatan dan sifat-sifat mekanis zat dinding sel itu sendiri.

\section{KESIMPULAN DAN SARAN}

\section{Kesimpulan}

Kesimpulan yang dapat diambil dari penelitian ini adalah sebagai berikut:

1. Berdasarkan uji eksperimental (pendekatan D) terhadap 4 jenis kayu tropis Indonesia maka displacement atau sesaran yang ditetapkan menurut standar Amerika $(0,38 \mathrm{~mm})$ dan Australia $(0,8 \mathrm{~mm})$ sebagai batas aman nilai disain acuan (Z) sambungan kayu geser ganda dengan paku dinilai terlalu rendah (relatif berbahaya) bila dibandingkan dengan nilai hasil pendekatan $A, B$ dan $C$ (teoritis menggunakan model batas leleh) yang overestimasi. Standar Indonesia (PKKI-61) menetapkan batas $Z$ pada sesaran $1,5 \mathrm{~mm}$ dipandang lebih moderat walaupun sedikit lebih tinggi dibandingkan 3 pendekatan lainnya sehingga lebih realistis dalam praktek aplikasi konstruksi. Bahkan apabila asumsi dan dasar perhitungan $Z$ yang digunakan pada sesaran $5,0 \mathrm{~mm}$ benar maka angka-angka nilai disain acuan berdasarkan pendekatan $D$ lebih realistis karena sangat mendekati hasil yang diperoleh secara teoritis.

2. Diameter paku berpengaruh terhadap nilai disain acuan tetapi tidak bersifat linier. Semakin besar diameter paku sampai $5,2 \mathrm{~mm}$ semakin tinggi pula kekuatan sambungannya tetapi nilai $Z$ tersebut kembali turun pada paku diameter $5,5 \mathrm{~mm}$.

3. Tidak selamanya berat jenis kayu mempengaruhi atau berbanding lurus dengan kekuatan/nilai disain acuan dari suatu sambungan kayu double shear dengan paku berpelat sisi baja.

\section{Saran}

berikut:

Saran dari penelitian ini adalah sebagai

1. Perlu penelitian lebih lanjut mengenai analisis terhadap model kerusakan yang dihasilkan dari sambungan geser ganda (double shearconnection) balok kayu dengan paku bulat atau paku tipe lain berpelat sisi papan/balok kayu.

2. Perlu penelitian lebih lanjut mengenai pengaruh kondisi dan kualitas bahan paku terhadap kekuatan sambungan kayu.

\section{DAFTAR PUSTAKA}

Anonim.2005. National Design Specification for Wood Construction. AF and PA American Wood Council. Washington, DC. 
2009.Identifikasi Kayu Indonesia. http://indonesianforest.com/frameset.php.htm. [ 28 Juni 2009]

Beery, W.H., Ifju, G., and McLain, T.E. 1983. Qualitative Wood Anatomy-Relating Anatomy to Transverse Tensile Strength. Wood Fiber Sci. 15:395-407.

Breyer, Donald E., Kenneth J.F., Kelly E.C., David G.P. 2007. Design of Wood Structures ASD/LRFD.Sixth Edition.New York.

Courney, T.H. 2000. Mechanical Behaviour of Materials. Chapt. 14:686-714. McGraw-Hill International Editions.

Direktorat Penyelidikan Masalah Bangunan. 1979. Peraturan Konstruksi Kayu Indonesia. NI-5. 1961. Yayasan Normalisasi Penyelidikan Masalah Bangunan.

Faherty, K.F and T.G. Williamson. 1989. Wood Engineering and Construction Handbook. McGraw-Hill Publishing Company. New York.

Forest Products Laboratory. 1999. Wood Handbook : Wood as an Engineering Material. USDA Forest Service. Forest Product Laboratory. USA.

Haygreen, J.G. and Bowyer, J.L. 1993. Forest Product and Wood Science, An Introduction. lowa State University Press. Ames, lowa.

Johansen, K.W. 1949. Theory of Timber Connections. Publications of International Asosiation for Bridge and Structural Engineering. Zurich. Switzerland.

Mansur, A.A. 2009. Kekuatan Sambungan Tarik Tiga Jenis Kayu Menurut Kombinasi Jumlah dan Diameter Paku. Departemen Hasil Hutan, Fakultas Kehutanan, Institut Pertanian Bogor. Bogor.

Muller, U., Wolfgang, G. and Alfred, T. 2003. Effects of Cell Anatomy on the Plastic and Elastic Behaviour of Different Wood Species Loaded Perpendicular to Grain. International Association of Wood Anatomist \& IAWA Journal. Vol. 24 (2) 2003. Published at the National Herbarium Netherland Leiden, The Netherlands.

Pandit, I.K.N. dan H. Ramdan. 2002. Anatomi Kayu : Pengantar Sifat Kayu sebagai Bahan Baku. Yayasan Penerbit, Fakultas Kehutanan IPB. Bogor.
Sadiyo, S dan Agustina, S. 2004. Kajian Hubungan Antara Kekuatan Sambungan Paku dengan Diameter Paku dan Berat Jenis Pada Beberapa Kayu Indonesia. Jurnal IImu dan Teknologi Kayu Tropis. Vol.3, No.1. Januari 2005. Masyarakat Peneliti Kayu Indonesia.

Sadiyo, S dan Sriyanto. 2009. Kekuatan Sambungan Tarik Double Shear Balok KayuPelat Baja Menurut Diameter dan Jumlah Paku Pada Sesaran Tertentu. Prosiding pada Seminar Nasional MAPEKI XII Bandung.

Ziannita, V. 2009. Nilai Desain Acuan Sambungan Double Shear Balok Kayu-Pelat Baja Empat Jenis kayu pada Tiga Diameter Paku Menurut Berbagai Analisis Pendekatan. Departemen Hasil Hutan Fakultas Kehutanan IPB, Bogor.

Surjokusumo, S., Sucahyo, S., Marzufli., A.A. Bismo dan A. Ch. Setyo. 1980. Sistem Keteknikan Kayu. Studi Sambungan Gang Nail dan Sambungan Paku. Fakultas Kehutanan, Institut Pertanian Bogor. Bogor.

Tabarsa, T. and Chui. Y.H. 2001. Characterizing Microscopic Behaviour of Wood under Transverse Compression, II. Effect of Species and Loading Direction. Wood Fiber Sci. 33: 223-232.

Tular dan Idris, 1981. Sekilas Mengenai Struktur Bangunan Kayu di Indonesia. Proceeding Lokakarya Standarisasi Kayu Bangunan. Departemen Hasil Hutan, Institut Pertanian Bogor. Bogor. 
Diterima : 03 Nopember 2009

\section{Sucahyo Sadiyo}

Mahasiswa Program Doktor Sekolah Pascasarjana IPB, Mayor Rekayasa \& Peningkatan Mutu (RPM) Hasil Hutan

Departemen Hasil Hutan, Fakultas Kehutanan, Institut Pertanian Bogor.

Gd. Fahutan JI. Lingkar Akademik, Kampus IPB Dramaga Bogor 16680.

(Forest Products Department, Faculty of Forestry, Bogor Agricultural University)

Tel./HP : 0251-8621285/081316772168

Fax. : :0251-8621285

E-mail : sucahyo@ipb.ac.id

Naresworo Nugroho, Surjono Surjokusumo dan Imam Wahyudi

Departemen Hasil Hutan, Fakultas Kehutanan, Institut Pertanian Bogor.

Gd. Fahutan JI. Lingkar Akademik, Kampus IPB Dramaga Bogor 16680.

(Forest Products Department, Faculty of Forestry, Bogor Agricultural University)

Tel./Fax.: 0251-8621285

E-mail : naresworo@yahoo.com

imyudarw@yahoo.com 